\title{
Effects of Concrete Grades on Strength Characteristics of Reinforced Concrete Slender Beams
}

\author{
"OLANITORI, LM; GBADAMOSI, IA \\ Department of Civil Engineering, Federal University of Technology, Akure, Ondo State, Nigeria. \\ *Corresponding Author Email: lekanolanitori@gmail.com; akindeji1759@gmail.com
}

\begin{abstract}
This paper presents the results of experimental study on the effects of concrete grades on strength characteristics of reinforced concrete slender beams. The materials used for the concrete were sand, crushed granite, stone dust, cement and water. Concrete mix ratios of 1:2:4 and 1:3:6 by weight with water-cement ratio of 0.6 was used. Four (4) reinforced concrete slender beams were cast, which were loaded with a point load at the beam centre. The results of the work show that, with decrease in concrete grade, there was corresponding decrease in ultimate load and shear capacity. For a drop of $16.67 \%, 38.67 \%$ and $62 \%$ in concrete grade there were corresponding decrease in the strength characteristics of beams by about $10.5 \%, 21.79 \%$ and $32.75 \%$ respectively. Therefore, decrease in concrete grade does not have the same percentage decrease in the strength characteristics of beams. Also, the mode of failure of reinforced concrete beams, depends not only on the ratio of the span to height of beam and the percentage area of reinforcement provided, but also on the concrete grade.
\end{abstract}

\section{DOI: https://dx.doi.org/10.4314/jasem.v23i5.12}

Copyright: Copyright ( 12019 Olanitori and Gbadamosi. This is an open access article distributed under the Creative Commons Attribution License (CCL), which permits unrestricted use, distribution, and reproduction in any medium, provided the original work is properly cited.

Dates: Received: 27 April 2019; Revised: 17 May 2019; Accepted 21 May 2019

Keywords: Concrete grades, slender beam, compressive strength, ultimate load, shear capacity

Concrete is one of the major construction material being used worldwide. Its great advantage is that as a man-made material, it can be poured into moulds of any shape where it sets, thus removing the necessity to form the material by carving, as is the case with stone. A further advantage is that its properties may be tailored to a considerable degree to meet different situations, (Olanitori and Olotuah 2005). As from 1970's, considerable improvement has taken place in the understanding of structural concrete and has been incorporated in the revised codes of practice. The British Standard CP110 (1972), has superseded the British Standard Codes of Practice CP114 (1957), for reinforced concrete. Similarly, in America the ACI Standard ACI 318-71 (1971) has replaced the previous standard ACI 318-63 (1963). The major aspects of the revised codes is the limit state approach for designing reinforced concrete structures and the separation of methods of concrete mix design procedures from that of concrete design considerations (Olanitori, 2013). The basic ingredients of concrete are: gravel (usually stone in the range of 5-20 mm), sand, cement and water. The cement is the only industrially produced ingredient and is used in relatively small quantities compared with the sand and gravel (typically about $15 \%$ by weight of the concrete). This makes concrete a cheap construction material compared with steel Narayanan and Beely
(2001). However, the quality of concrete produced depends on the quality of its constituent materials and their mix ratios; the higher the percentage of clay/silt content of sand, the lower the characteristic strength (Olanitori and Olotuah, 2005). Olanitori L.M. (2012), determined the cost implication of mitigating the effect of clay/silt content of sand using mathematical models. There is strong evidence that aggregate type is a factor in the strength of concrete. Ezeldin and Aitcin (1991) compared concretes with the same mix proportions containing four different coarse aggregate types. They concluded that, in highstrength concretes, higher strength coarse aggregates typically yield higher compressive strengths, while in normal-strength concretes, coarse aggregate strength has little effect on compressive strength. Other research has compared the effects of limestone and basalt on the compressive strength of high-strength concrete, Giaccio et al. (1992). Tests by Zhou et al. (1995) show that compressive strength increases with an increase in coarse aggregate size. However, most other studies disagree.

Pawar et al (2016), studied the effects of gradation of aggregates on properties of concrete and concluded that fine aggregate gradation has more detrimental effect on concrete properties than coarse aggregate gradations. In their work, Albarwary et al (2017), on 
the effect of aggregate maximum size upon compressive strength of concrete, concluded that, in general the compressive strength of concrete increases when the maximum size of aggregate decreases and the maximum aggregate size strongly influences the concrete strength. Also, the test results also show that the optimum concrete strength is reached by using aggregates of $9.5 \mathrm{~mm}$ maximum size. Petrounias et al (2018) deduced from their study that, mineralogy and microstructure of the coarse aggregates affected the final strength of the concrete specimens. Tunio et al (2019) noted that coarse aggregate gradation, cementaggregate proportion and w/c ratio significantly affect the compressive strength of no fines concrete. Reinforced concrete beams can fail by bending, by shearing or by flexural-shearing mode of failures. Olanitori and Afolayan (2014) noted that, most reinforced concrete structures failed by shearing, and this is because there exist discrepancies between estimated shear capacity based on equations from the codes and, the actual shear capacity and concluded that more research work should be conducted on models that can predict the shear capacity of reinforced concrete beams more accurately. Olanitori and Olotuah (2005), noted in their study, that targeted concrete strength may not be achieved due to the silt/clay content in the fine aggregate. The danger of not achieving the recommended strength of concrete by consultant structural engineer during construction, is that the structure built from such concrete with reduced compressive strength will have their structural integrity compromised, and may not be able to carry its intended load, which might ultimately lead to its collapse. Therefore, the aim of this paper is to investigate the effects of concrete grades on strength characteristics of reinforced slender beams.

\section{MATERIALS AND METHODS}

The materials used for the production of concrete for this research work were Ordinary Portland cement of grade 32.5 , fine aggregates, stone dust, crushed granite of $20 \mathrm{~mm}$ maximum size and portable water. The basic material tests were done according to British standards (BS 882, 1992; BS 812, 1985 and BS 1881, 1983). The yield strength of reinforcing bar used, was $370 \mathrm{~N} / \mathrm{mm}^{2}$. The proportions of materials for beam concrete mixes are given in table 1 .

Four (4) reinforced concrete slender beams were cast from concrete grades of $5.7 \mathrm{~N} / \mathrm{mm}^{2}, 9.2 \mathrm{~N} / \mathrm{mm}^{2}, 12.5$ $\mathrm{N} / \mathrm{mm}^{2}$ and $15 \mathrm{~N} / \mathrm{mm}^{2}$ respectively. The beams were loaded with a point load at the beam centre using universal testing machine. The shear span to depth ratio of the beam loaded at the centre with a point load was 3.8. Each of the beams was reinforced at the top and bottom with 2 Y $12 \mathrm{~mm}$ bars, with shear reinforcement of $\mathrm{Y} 8$ bars at $100 \mathrm{~mm}$ centres. The cross-sectional dimension of the beams was $100 \mathrm{~mm} \mathrm{x}$ $150 \mathrm{~mm}$ with overall length of $1000 \mathrm{~mm}$.

Table 1: Proportion of Material for Beam Concrete Mixes

\begin{tabular}{lllll}
\hline Material & \multicolumn{4}{c}{ Quantity } \\
\hline & $5.7 \mathrm{G}$ & $9.2 \mathrm{G}$ & $12.5 \mathrm{G}$ & $15 \mathrm{G}$ \\
Water $/$ Cement ratio & 0.6 & 0.6 & 0.6 & 0.6 \\
Water $\left(\mathrm{kg} / \mathrm{m}^{2}\right)$ & 3 & 4.8 & 4.8 & 4.8 \\
Cement $\left(\mathrm{kg} / \mathrm{m}^{3}\right)$ & 5 & 8 & 8 & 8 \\
Fine $\quad \%$ Sand & 15 & 16 & 12.8 & 6.4 \\
Agg. $\left(\mathrm{kg} / \mathrm{m}^{2}\right) \%$ Stone dust & - & - & 3.2 & 9.6 \\
Coarse $\mathrm{Agg}\left(\mathrm{kg} / \mathrm{m}^{2}\right)$ & 30 & 32 & 32 & 32 \\
Total Volume $\left(\mathrm{m}^{2}\right)$ & 0.015 & 0.015 & 0.015 & 0.015 \\
\hline
\end{tabular}

The load was applied at a steady rate on the beam until failure occurred. The readings for the collapsed load of the beams were taken, with the beam displacements. The flexural and shear strengths of the beams were determined from the readings taken. The flexural tests carried out on the beams were in accordance with BS EN 12390-5 (2009).

\section{RESULTS AND DISCUSSION}

The beams were subjected to a point load at the beam centre, until the beam failure occurred. Results of the flexural tests are presented in Table 2. The bending stress of the beams was calculated using Equation 1.

$$
\sigma_{A B S}=\frac{3 P L}{2 b d^{2}}
$$

Where: $\mathrm{P}=$ the ultimate load, $\mathrm{L}=$ beam span, $\mathrm{b}=$ beam width and $d=$ effective depth of beam $=131 \mathrm{~mm}$.

From Table 2, beams B1, B2, B3, and B4 were loaded with a point load at the centre and failed under 40.03 $\mathrm{kN}, 46.55 \mathrm{kN}, 53.01 \mathrm{kN}$ and $59.52 \mathrm{kN}$ loads respectively. The shear forces at failure were 20.02 $\mathrm{kN}, 23.28 \mathrm{kN}, 26.51 \mathrm{kN}$ and $29.76 \mathrm{kN}$ while the displacements at failure were $15.67 \mathrm{~mm}, 20.58 \mathrm{~mm}$, $24.97 \mathrm{~mm}$, and $28.70 \mathrm{~mm}$ for beams B1, B2, B3 and B4 respectively. These results indicated that the displacements depend not only the percentage area of reinforcements provided, but also on the beam concrete grades. From Table 3, for beam B1 with 5.7 concrete grade, the ultimate load at failure was 40.03 $\mathrm{kN}$, while for beams B2, B3 and B4 with concrete grades of 9.2, 12.5 and 15 failed at the ultimate loads of $46.55 \mathrm{kN}, 53.27 \mathrm{kN}$ and $59.52 \mathrm{kN}$ respectively. This shows that as concrete grade increases, the ultimate load increases. 
Table 2: Results of flexural test on Beams

\begin{tabular}{llllllll}
\hline $\begin{array}{l}\text { Beam } \\
\text { No }\end{array}$ & $\begin{array}{l}\text { Weight } \\
(\mathbf{k g})\end{array}$ & $\begin{array}{l}\text { Position } \\
\text { of Load }\end{array}$ & $\begin{array}{l}\text { Concrete grades } \\
\left(\mathbf{N} / \mathbf{m m}^{\mathbf{2}}\right)\end{array}$ & $\begin{array}{l}\text { Load at } \\
\text { Failure }(\mathbf{k N})\end{array}$ & $\begin{array}{l}\text { Bending Strength } \\
\left(\mathbf{N} / \mathbf{m m}^{2}\right)\end{array}$ & $\begin{array}{l}\text { Shear } \\
\text { Force }(\mathbf{k N})\end{array}$ & $\begin{array}{l}\text { Displacement } \\
(\mathbf{m m})\end{array}$ \\
\hline B1 & 43.60 & At center & 5.7 & 40.03 & 26.24 & 20.02 & 15.67 \\
B2 & 42.70 & At center & 9.2 & 46.55 & 30.52 & 23.28 & 20.58 \\
B3 & 44.00 & At center & 12.5 & 53.01 & 34.75 & 26.76 & 24.97 \\
B4 & 44.90 & At center & 15 & 59.52 & 39.02 & 29.76 & 28.70 \\
\hline
\end{tabular}

Table 3: The effect of Concrete grade on strength characteristics of the Experimental beams

\begin{tabular}{lllll}
\hline $\begin{array}{l}\text { Beam } \\
\text { type }\end{array}$ & $\begin{array}{l}\text { Concrete } \\
\text { grade }\end{array}$ & $\mathbf{P}_{\text {AUL }}(\mathbf{k N})$ & $\mathbf{V}_{\text {AUS }}(\mathbf{k N})$ & $\begin{array}{c}\boldsymbol{\sigma}_{\boldsymbol{A B S}} \\
\left(\mathbf{N} / \mathbf{m m}^{\mathbf{2}}\right)\end{array}$ \\
\hline B1 & 5.7 & 40.03 & 20.02 & 26.24 \\
B2 & 9.2 & 46.55 & 23.28 & 30.52 \\
B3 & 12.5 & 53.27 & 26.64 & 34.75 \\
B4 & 15 & 59.52 & 29.76 & 39.02 \\
\hline
\end{tabular}

From Table 4, for $16.67 \%, 38.67 \%$ and $62.00 \%$ drop in concrete grades, there were $10.50 \%, 21.79 \%$ and $32.75 \%$ corresponding drop in the ultimate loads and shear capacities of the beams respectively. The ratio of percentage drop of strength characteristic (i.e. $\mathrm{P}_{\mathrm{AUL}}$, $\mathrm{V}_{\mathrm{AUS}}$ and $\sigma_{\mathrm{ABS}}$ ) of beams $\mathrm{B} 1, \mathrm{~B} 2$ and $\mathrm{B} 3$ when compared with that of $\mathrm{B} 4$ were $0.53,0.56$ and 0.63 respectively. Therefore, decrease in concrete grade does not have the same percentage decrease in the strength characteristics of beams. Hence strength characteristics of reinforced concrete beams will be reduced by $53 \%$ to $63 \%$ of the percentage decrease of concrete grade.

Table 4: The Effect of Percentage Drop in Concrete Grade on Strength Characteristics of the Experimental beams

\begin{tabular}{|c|c|c|c|c|}
\hline $\begin{array}{l}\text { \% Drop in } \\
\text { Concrete } \\
\text { Grade }\end{array}$ & $\begin{array}{l}\text { \% Drop } \\
\text { in } \text { P }_{\mathrm{AUL}} \\
(\mathrm{kN})\end{array}$ & $\begin{array}{ll}\% & \text { Drop } \\
\text { in } & V_{\text {AUS }} \\
(\mathrm{kN}) & \\
\end{array}$ & $\begin{array}{l}\% \text { Drop in } \\
\sigma_{\mathrm{ABS}} \\
(\mathrm{kNm})\end{array}$ & $\begin{array}{l}\% \text { Drop } \\
\text { in } \\
\mathrm{S}_{\mathrm{SC}} / \% \mathrm{C}_{\mathrm{G}}\end{array}$ \\
\hline 62.00 & 32.75 & 32.73 & 32.75 & 0.53 \\
\hline 38.67 & 21.79 & 21.77 & 21.78 & 0.56 \\
\hline 16.67 & 10.50 & 10.48 & 10.50 & 0.63 \\
\hline 0.00 & 00.00 & 0.00 & 0.00 & - \\
\hline
\end{tabular}

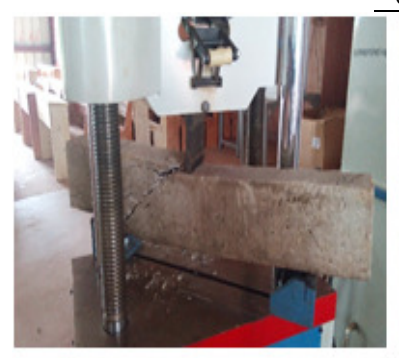

Fig 1: Mode of Failure of Beam B1

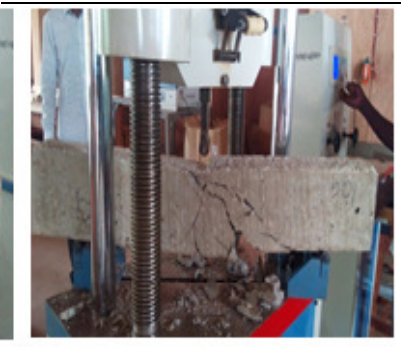

Fig 2: Mode of Failure of Beam B2

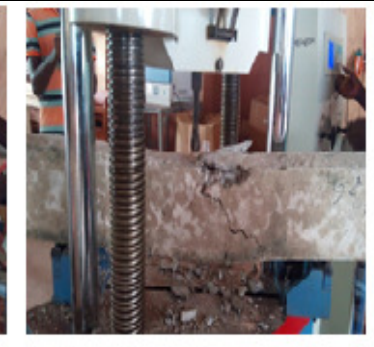

Fig 3: Mode of Failure of Beam B3

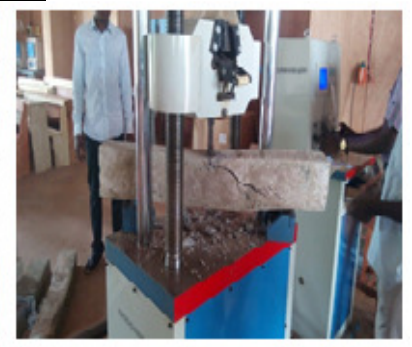

Fig 4: Mode of Failure of Beam B4
Figure 1 shows the mode of failures of beam B1. For beam B1 with concrete grade of 5.7 and deflection $15.67 \mathrm{~mm}$ at the ultimate load $40.03 \mathrm{kN}$, failed by shearing at the support. From Figure 2, beam B2 with concrete grade of 9.2 , failed by bending at a load of $46.55 \mathrm{kN}$, and $20.58 \mathrm{~mm}$ deflection. Figure 3 gives mode of failure of beam B3. Beam B3 failed by bending at a load of $53.01 \mathrm{kN}$ with $24.97 \mathrm{~mm}$ deflection. From Figure 4, beam B4 failed by flexuralshearing mode of failure at failure load of $59.52 \mathrm{kN}$, with $28.70 \mathrm{~mm}$ deflection. This shows that mode of failure of reinforced concrete beams, depends not only on the ratio of the span to height of beam and the percentage area of reinforcement provided, but also on the concrete grade.
Conclusion: With decrease in concrete grade, there is corresponding decrease in the ultimate load and shear capacity of reinforced concrete beams. Decrease in concrete grade does not have the same percentage decrease in the strength characteristics of beams. Strength characteristics of reinforced concrete beams will be reduced by $53 \%$ to $63 \%$ of the percentage decrease of concrete grade. Also, the mode of failure of reinforced concrete beams, depends not only on the ratio of the span to height of beam and the percentage area of reinforcement provided, but also on the concrete grade.

Acknowledgements: The authors would like to thank the Department of Civil Engineering, Federal University of Technology Akure, Ondo State, and 
Department of Civil Engineering, Elizade University, Ilara-Mokin, Ondo State, for allowing us to use their structural engineering laboratories.

\section{REFERENCES}

Albarwary, IHM; Aldoski, ZNS; Askar, LK (2017). Effect of Aggregate Maximum Size upon Compressive Strength of Concrete. J. Univ. Duhok (Pure and Eng. Sci.). 20(1): 790-797.

American Concrete Institute. (1963). ACI 318-63: Building Code Requirements for Reinforced Concrete. American Concrete Institute. Michigan, USA.

American Concrete Institute. (1971). ACI 318-71: Building Code Requirements for Reinforced Concrete. American Concrete Institute. Michigan, USA.

British Standards Institution. (1983). BS 1881-1983: Testing Concrete - Part 120: Method for Determination of Concrete Cores. British Standards Institution. London.

British Standards Institution. (1985). BS 812-1985: Testing aggregates - Part 103: Methods for determination of particle size distribution-section 103.1- Sieve tests. British Standards Institution. London.

British Standards Institution. (1992). BS 882-1992: Specification for aggregates from natural sources for concrete. British Standards Institution. London.

British Standards Institution. (2009). BS EN 123905:2009: Testing Hardened Concrete. Part 5: Flexural Strength of Test Specimens. British Standards Institution. London.

CP 110 (1972). Code of Practice for structural us of Concrete: Part I - Design, Materials and Workmanship. British Standards Institution, London.

CP 114 (1957). The Structural use of Reinforced Concrete in Buildings (amended in 1965). British Standards Institution, London.

Ezeldin, AS; Aitcin, PC (1991). Effect of Coarse Aggregate on the Behaviour of Normal and High Strength Concretes. Journal of Cement, Concrete and Aggregates. 13(2): 121-124.

Giaccio, GR; Violini, D; Zappitelli, J; Zerbino, R (1992). High Strength Concrete Incorporating Different Coarse Aggregates. ACI Materials Journal. 89(3): 242-246.
Narayan, RS; Beely, AW (2001). Introduction to Design for Civil Engineers. Spon Press, London and New York.

Olanitori, LM (2012). Cost implication of mitigating the effect of clay/silt content of sand on concrete compressive strength. J. Civil Engineer. Urbanism. 2(4): 143-148.

Olanitori, LM (2013). Codes of Practice: Prerequisite for Quality Structural Design and Management of Buildings in Nigeria. $5^{\text {th }}$ West Africa Built Environment Research (WABER) Conference. 12-14 August 2013. Accra, Ghana. S. Laryea and S. Agyepong (eds). Pp 283-291.

Olanitori, LM; Afolayan, JO (2014). Effects of Pit-Sand on Resistance Capacities of Reinforced Concrete Space Framed Structures. Open Journal of Civil Engineering (OJCE). 4(4): 328-337.

Olanitori, LM; Olotuah, AO (2005). The effect of clayey impurities in sand on the crushing strength of concrete (a case study of sand in Akure metropolis, Ondo State, Nigeria). Proceedings of $30^{\text {th }}$ Conference on 'Our World in Concrete and Structures'. 23-24 August 2005 Singapore. Dr. C.T. Tam, Prof. K.C.G. Ong and Dr. T.H. Tan (eds). Pp. 373-376.

Pawar, C; Sharma, P; Titiksh, A (2016). Gradation of Aggregates and its Effects on Properties of Concrete. Inter. J. Trend. Develop. 3(2): 581-584.

Petrounias, P; Giannakopoulou, PP; Rogkala, A; Stamatis, PM; Lampropoulou, P; Tsikouras, B; Hatzipanagiotou, K (2018). The Effect of Petrographic Characteristics and PhysicoMechanical Properties of Aggregates on the Quality of Concrete. Minerals (MDPI). 8, 577.

Tunio, ZA; Memon, BA; Memon, NA (2019). Effect of Coarse Aggregate Gradation and Water-Cement Ratio on Unit Weight and Compressive Strength of No-fines Concrete. Engineer. Technol. Appl. Sci. Res. 9(1): 3785-3788.

Zhou, FP; Barr, BIG; Lydon, FD (1995). Fracture Properties of High Strength Concrete with Varying Silica Fume Content and Aggregates. Cement. Concrete Res. J. 25(3): 543-552. 